\title{
Exploration of Balanced Scorecard-Based Government Performance Management in China
}

\author{
Ge Leilei \\ Department of Public Administration \\ University of International Relations \\ Beijing, P.R China, 100091
}

\begin{abstract}
The extremely rapid economic development in China has made public sector organizations, especially local governments, increasingly under pressure to meet the various demands from diverse stakeholders. Local governments not only need to improve their performance but also need to demonstrate such improvements through an effective performance management system. Although balanced scorecard (BSC) has been successfully applied in western countries, rare cases of BSC applied in China's local governments are reported. This paper demonstrates the procedures and experiences for the design and implementation of BSC in China's local governments, using the case of Yanqing County in Beijing. The issues and challenges were also discussed.
\end{abstract}

Keywords-local government; balanced scorecard; performance management

\section{INTRODUCTION}

Performance management plays a critical role in human resources management in public sectors, which also is one of the three important questions in public administration [1]. Due to the diversity and complexity of government strategies, demands from multiple stakeholders must be considered. Besides that, governmental organizations might be expected to follow different strategies from private-sector companies, given that their primary objective is to satisfy various needs of citizens in the society, rather than to solely pursue financial success. Meanwhile, governmental organizations are likely to run into various transactional affairs, making strategic focusing difficult or even deviate from the strategies. Consequently, the alignment and communication within governmental organizations are expected to be more important than their private sector counterparts. Therefore, there is an urgent need of systematic and integrated framework for governments to respond to these various issues. The balanced scorecard (BSC), a comprehensive performance measurement and strategic management system proposed by Kaplan and Norton, can be an invaluable tool to help local governments to transform their strategies into actions and consequently improve the performance $[2,3]$.

\section{Existing Problems with Government PERformance MANAgEMENT In ChinA}

The practicing and exploration of government performance management (GPM) in China began as early as 1980s. In retrospection of its development during the past four decades, great progress has been achieved, however a number of problems still exist. These can be summarized as the following six aspects. 1. Lack of systematic thinking. Many GPM practices emphasize on a certain key decision. For example, "government review by ten thousand people" puts emphasis on the subjects of evaluation. 2. Lack of balance concept. The results and short-term economic benefits, rather than the process of performance management and long-term strategic development, are emphasized. 3. Neglect of strategic focusing. In practice government organizations are likely to be caught in various transactional affairs, making strategic focusing difficult or even deviate from the strategies. 4. Neglect of synergistic effects. Alignment between upper and lower levels of government organizations is not sufficient, which, to some extent, leads to waste of resources or competition. 5. Emphasis on measurement rather than management. This is due to the fact that government managers are more familiar with performance measurement than other aspects of performance management, making the realization of managerial, developmental and strategic goals difficult. 6. Emphasis on principles rather than methods. Currently, technical supports for GPM are not available, and some government organizations still use obsolete methods incapable of effective performance measurement. Therefore, an urgent need exists as to the deployment of an effective management system for these problems and issues.

Kaplan and Norton claimed that BSC may be more effective in non-profit organizations, which have multiple strategic goals to achieve [4]. In the last two decades, an increasing number of successful cases in USA, Australian, New Zealand and Korean governments used BSC to respond to and deal with pressures and challenges that China faces as well. Recently, after years of extensive management, China began to emphasize and advocate sustainable development strategy. Considering that BSC can promote the balance between longterm strategy and short-term economic success, and its strategic, balanced and synergic characters, it is also can be adopted in China to improve the comprehensive performance of local governments as an effective strategic management and performance management system. In this study, BSC is used as the theoretical framework for the systematic design of China's GPM, and the case of Environment Protection Bureau of Yanqing County will be demonstrated to explain the design of such a BSC-based GPM system. 


\section{Procedures of Applying BSC IN CHINA's LOCAL GOVERNMENT}

The design of GPM system in China's local government consists of five steps. The first step is to design government strategy map. Based on government organization's mission,

core values, vision and strategy, the strategy map and strategic

objectives for each perspective are designed at the organization level. The second step is the development of government BSC based on government strategy map. According to the strategy map and strategic objectives, measures, targets, leaders-incharge and initiatives to complete the BSC are worked out. The third step is to design GPM form. Based on government organizations' BSC, performance measurement form used for daily performance management was formulated. The fourth step is to develop BSC for managers and employees. According to responsibilities for different positions, BSC and performance measurement forms are customarily prepared by cascading, decomposing and supplementing strategic objectives at the organizational level. The fifth step is to design performance measurement form for managers and employees.

\section{RESCALING BALANCED SCORECARD FOR LOCAL GOVERNMENTS IN CHINA}

In 1990s, balanced scorecard gained significant success in helping private companies translate their strategies into a balanced set of measures to improve their comprehensive performance. Originally, the BSC model was developed in "for-profit" organizations, therefore it may not be very suitable for "not-for-profit" organizations [5]. Besides, China has its own specific political system and strategic positioning. Considering all these factors, changes need to be made to BSC before it can be applied in China's local governments, in order to make a scientific, systematic, and easy-to-implement BSC system.

The BSC system consists of four perspectives: financial performance, customer service, work processes and employee learning and growth. Given that financial profit is not the primary objective of governments, success of governments should be measured by how effectively and efficiently they can meet the needs of citizens. Financial considerations can play an enabling or constraining role but will rarely be the primary objective [6]. Typically, most governments prioritize nonfinancial outcome measures, such as customer or stakeholder perspectives, rather than a financial perspective at the top [5]. In some cases, the four perspectives can be reduced to three. The perspectives of financial performance and employee learning and growth can be combined as on perspective of supporting measures at the bottom of the strategy map to support the other two perspectives, i.e. perspectives of implementation path and stakeholders. Also, considering the communication style of civil servants in China, the label of each perspective should be modified to make them more easily to understand and communicate. The label of each perspective is shown in Figure 1.

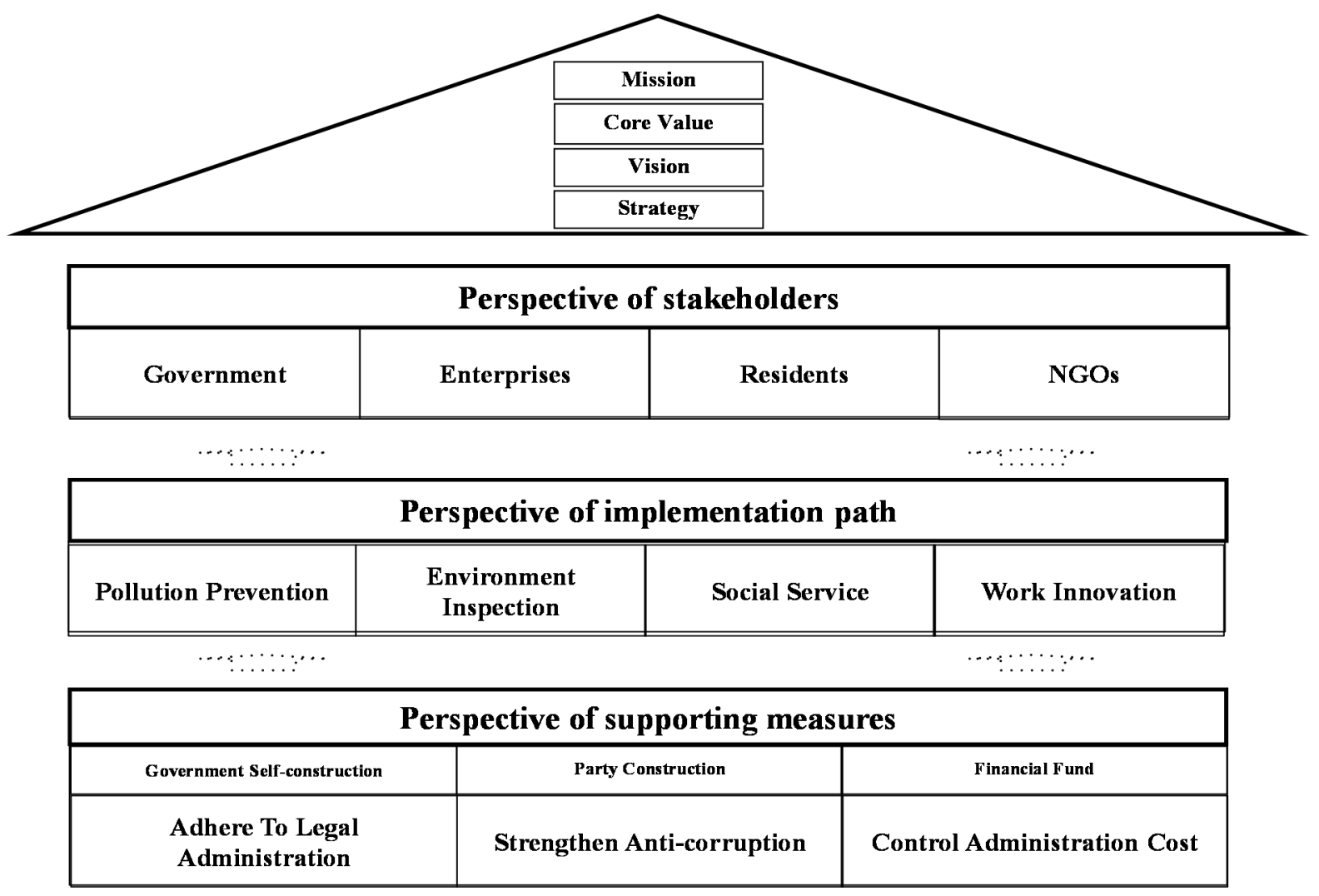

Fig. 1. Balanced Scorecard of Environmental Protection Agency of Yanqing County 


\section{BALANCED SCORECARD DEPLOyed FOR YANQING COUNTY OF BEIJING}

Yanqing County is at the suburb of Beijing, where the Great Wall is located. The tourism industry is one of its major economic sources. Environmental protection is a particularly important task for this county. To improve its performance and demonstrate accountability to the society, the Environment Protection Bureau of Yanqing County chose BSC. Through a wide range of discussion among employees of the bureau, its mission, core values, vision and strategy were clarified. Its mission is to strive to provide Yanqing people with a healthy and clean environment. Its core values are diligent and honest, efficient and pragmatic, exploitive and innovative. Its vision is to make Yanqing a demonstration area of Green Beijing by 2020. And the strategy is to strictly enforce environmental access standard, strengthen pollution control, ensure environmental safety, promote public participation, and ensure benign cycle of the ecological system. In the following section, the strategy map and BSC of the EPB in Yanqing County will be described, shown in Figures 1 and 2.

The overall framework of the strategy map of EPB is shown as Figure 1, which looks like a house. From top to bottom, the roof represents EPB's mission, core values, vision and strategy. The major body can be divided into three floors. The third floor represents the perspective of stakeholders, including the government, enterprises, non-governmental organizations and residents; the second floor is the perspective of implementation path, including EPB's four most important strategic themes: pollution prevention, environmental monitoring, community services, and work innovation. The bottom floor is the perspective of supporting measures, including intangible assets used to provide key supports for the implementation path, such as the strengthening of anticorruption and control administration cost. Overall, from top to

bottom, the organization's mission, core values, vision and

strategy can be implemented and from bottom to top, each perspective is supported by each other, allowing organization vision and strategy to be achieved.

Guided by the mission, core values, vision and strategy of EPB, strategic objectives were set for perspectives of the strategy map, such as "reduction of total amount of emissions" from the perspective of stakeholders and "perfect environmental monitoring system" from the perspective of implementation path, as shown in Figure 2. Based on the strategy map and strategic objectives, measures, objectives, weights and initiatives of the BSC for EPB were proposed. Furthermore, performance measurement form for daily performance management by EPB was proposed as well.

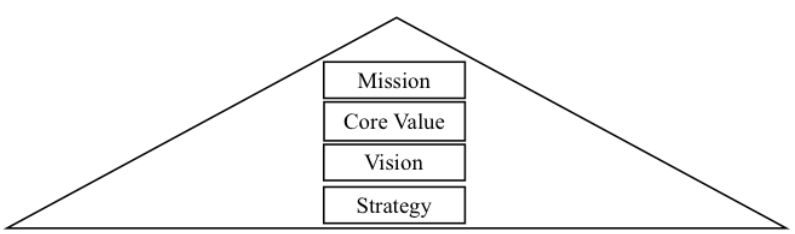

\begin{tabular}{|c|c|c|c|c|c|c|c|}
\hline & & & $\begin{array}{l}\text { Perspect- } \\
\text { ives }\end{array}$ & Objectives & Measures & Weight & Initiatives \\
\hline \multicolumn{3}{|c|}{ Perspective of stakeholders } & \multirow{4}{*}{ Stakeholders } & $\begin{array}{c}\text { Improve Environment } \\
\text { Quality }\end{array}$ & $\begin{array}{l}\text { Proportion of days when air } \\
\text { quality is above level } 2\end{array}$ & $84 \%$ & Clean air ation plan \\
\hline \multirow{2}{*}{$\begin{array}{c}\text { Improve } \\
\text { Environment Quality }\end{array}$} & \multirow{2}{*}{$\begin{array}{c}\text { Reduce Total } \\
\text { Amount of } \\
\text { Emissions } \\
\end{array}$} & \multirow{2}{*}{$\begin{array}{c}\text { Ensure } \\
\text { Environmental } \\
\text { Safety } \\
\end{array}$} & & $\begin{array}{c}\text { Reduce Total Amount } \\
\text { of Emissions }\end{array}$ & COD/carbon dioxide emission & $\mathrm{OK}$ & $\begin{array}{c}\text { Reduction } \\
\text { implementation plan } \\
\end{array}$ \\
\hline & & & & $\begin{array}{l}\text { Ensure Environmental } \\
\text { Safety }\end{array}$ & $\begin{array}{l}\text { Occurrence of Major } \\
\text { environmental pollution accidents }\end{array}$ & 0 time/yr & $\begin{array}{r}\text { Environmental } \\
\text { emergency plan }\end{array}$ \\
\hline \multicolumn{3}{|l|}{ a............ } & & $\begin{array}{c}\text { Improve Service } \\
\text { Quality }\end{array}$ & $\begin{array}{l}\text { Satisfaction level on } \\
\text { environmental protection }\end{array}$ & $90 \%$ & Satisfaction survey \\
\hline \multicolumn{3}{|c|}{ Perspective of implementation path } & \multirow{3}{*}{$\begin{array}{l}\text { Implementati } \\
\text { on path }\end{array}$} & $\begin{array}{c}\text { Strict Construction } \\
\text { Project Approval }\end{array}$ & Approval rate of new projects & $100 \%$ & $\begin{array}{c}\text { Construction project } \\
\text { licensing process }\end{array}$ \\
\hline \multirow{2}{*}{$\begin{array}{l}\text { Strict Construction } \\
\text { Project Approval }\end{array}$} & \multirow{2}{*}{$\begin{array}{c}\text { Perfect } \\
\text { Environmental } \\
\text { Monitoring System } \\
\end{array}$} & \multirow{2}{*}{$\begin{array}{c}\text { Increase Intensity of } \\
\text { Environmental } \\
\text { Inspection } \\
\end{array}$} & & $\begin{array}{c}\text { Perfect Environmental } \\
\text { Monitoring System }\end{array}$ & Completion of monitoring & $100 \%$ & EM statement \\
\hline & & & & $\begin{array}{c}\text { Increase Environmental } \\
\text { Inspection } \\
\end{array}$ & $\begin{array}{l}\text { Field monitoring coverage of } \\
\text { major pollution sources }\end{array}$ & $90 \%$ & $\begin{array}{c}\text { Environmental } \\
\text { monitoring plan }\end{array}$ \\
\hline a............... & & a.............. & Perspective & $\begin{array}{c}\text { Protect Citizens } \\
\text { 'Environmental Rights } \\
\end{array}$ & $\begin{array}{l}\text { Clearance rate of environmental } \\
\text { petition }\end{array}$ & $100 \%$ & $\begin{array}{c}\text { Petition working } \\
\text { procedure }\end{array}$ \\
\hline \multicolumn{3}{|c|}{ Perspective of supporting measures } & \multirow{3}{*}{$\begin{array}{l}\text { Supporting } \\
\text { measures }\end{array}$} & $\begin{array}{c}\text { Adhere To Legal } \\
\text { Administration }\end{array}$ & $\begin{array}{l}\text { Number of lost administrative } \\
\text { cases }\end{array}$ & 0 time/yr & $\begin{array}{c}\text { Regulation of lawful } \\
\text { administration }\end{array}$ \\
\hline $\begin{array}{l}\text { Government Self- } \\
\text { construction }\end{array}$ & Party Construction & Financial Fund & & $\begin{array}{c}\text { Enhance administrative } \\
\text { accountability }\end{array}$ & $\begin{array}{l}\text { Number of administrative } \\
\text { accountability }\end{array}$ & 0 time/yr & $\begin{array}{c}\text { Administrative } \\
\text { accountability act }\end{array}$ \\
\hline $\begin{array}{l}\text { Adhere To Legal } \\
\text { Administration }\end{array}$ & $\begin{array}{l}\text { Strengthen Anti- } \\
\text { corruption }\end{array}$ & $\begin{array}{c}\text { Control } \\
\text { Administration Cost }\end{array}$ & & $\begin{array}{c}\text { Control Administration } \\
\text { Cost }\end{array}$ & $\begin{array}{l}\text { Ratio of Sangong consumption in } \\
\text { total expenditure }\end{array}$ & $\mathrm{X} \%$ & $\begin{array}{c}\text { Financial management } \\
\text { regulation }\end{array}$ \\
\hline
\end{tabular}

Fig. 2. Balanced Scorecard of EPB

It is well known that different levels of performances exist, such as organizational, departmental and individual performance. Once the EPB's organizational performance measurement form is formulated, the design of performance measurement forms for EPB's managers and employees becomes easy. By looking into position responsibilities, BSC and performance measurement forms are customized by cascading, decomposing and supplementing strategic objectives from the organizational level. In this way, the alignment and communication problems can, to some extent, be solved. 


\section{CONCLUSION}

In summary, five steps were developed for the design of the government performance management system using BSC. To get feedback on BSC system performance, we interviewed several managers in EPB, who responded positively by agreeing that BSC can indeed help "avoid information fatigue, clarify strategy, communicate and link goals, and enable strategic feedback". More importantly, "organization performance could be translated into individual actions". Meanwhile, some managers pointed out that it's of great importance to train employees by providing them opportunities to learn BSC theory before the BSC system is officially run. By doing so, problems and challenges, such as employees' resistance to the new system or lack of technique, can be solved. Therefore, the proposed BSC-based GPM system is a meaningful exploration that will advance China's GPM to a new level. It may also be used as a reference by other countries in the design of BSC-based GPM system.

\section{REFERENCES}

[1] R.D. Behn, "The big questions of public management". Public administration review, 1995, pp. 313-324

[2] R.S. Kaplan and D.P. Norton, "Using the balanced scorecard as a strategic management system". Harvard business review, 1996. 74(1), pp 75-85.

[3] R.S. Kaplan and D.P. Norton, "The balanced scorecard: translating strategy into action". 1996, Harvard Business Press.

[4] P.R. Niven, "Balanced scorecard: Step-by-step for government and nonprofit agencies". 2011, John Wiley \& Sons.

[5] D. Quinlivan, "Rescaling the balanced scorecard for local government". Australian Journal of Public Administration, 2000. 59(4), pp. 36-41.

[6] R.S. Kaplan, "Strategic performance measurement and management in nonprofit organizations". Nonprofit management and Leadership, 2001. 11(3), pp. 353-370. 